\title{
Modeling Hepatitis C Virus Therapies Combining Drugs and Lectin Affinity Plasmapheresis
}

\author{
Richard H. Tullis ${ }^{a}$ R. Paul Duffin ${ }^{a}$ Thomas E. Ichim ${ }^{b}$ James A. Joyce ${ }^{a}$ \\ Nathan W. Levin ${ }^{c}$ \\ ${ }^{a}$ Aethlon Medical Inc. and ${ }^{b}$ Medistem Inc., San Diego, Calif., and ${ }^{c}$ Renal Research Institute, New York, N.Y., USA
}

\section{Key Words}

Hepatitis C virus $\cdot$ Lectin affinity $\cdot$ Hemodialysis $\cdot$

Plasmapheresis • Mathematical models $\cdot$ Galanthus nivalis

agglutinin

\begin{abstract}
Hepatitis $C$ virus (HCV) infection can be cured by standard pegylated interferon (IFN) + ribavirin drug therapy in 30$50 \%$ of treatment-naïve genotype $1 \mathrm{HCV}$ patients. Cure rate is defined as a sustained viral response measured 6 months after the end of treatment. Recently, Fujiwara et al. [Hepatol Res 2007;37:701-710], using a double-filtration plasmapheresis (DFPP) technique, showed that simple physical reduction in circulating $\mathrm{HCV}$ using a 1-week pretreatment increased the cure rate for treatment-naïve type $1 \mathrm{HCV}$ patients from 50 (controls) to $78 \%$ (treated). For previous nonresponders, the cure rate increased from 30 to $71 \%$. This effect occurs even though the DFPP per treatment HCV viral load reduction averaged $26 \%$. In clinical studies discussed here, a lectin affinity plasmapheresis (LAP) device caused an estimated $41 \%$ decrease in viral load as previously reported. A more detailed analysis using normalized data to correct for any variations in initial viral load gave an average 29\% per treatment viral load reduction in 5 HCV-positive dialysis patients. The latter data indicate that continuous application of LAP could bring HCV viral load to undetectable levels in 4.1
\end{abstract}

days. Compared to DFPP, the LAP approach has the advantage that no plasma losses are incurred. In addition hemopurification can be carried out for extended periods of time analogous to continuous renal replacement therapy for the treatment of acute kidney failure, making the process much more effective. Calculations based on these data predict that continuous hemopurification would substantially increase the rate of viral load reduction (approx. 14-fold) and therefore increase the cure rate for HCV standard-of-care drug therapies without adding additional drugs and their associated side effects.

Copyright $\odot 2010$ S. Karger AG, Basel

\section{Introduction}

Hepatitis $\mathrm{C}$ virus (HCV) infections currently affect more than 3.9 million people in the USA [1] and over 180 million worldwide. The virus is responsible for liver damage that drives much of the need for liver transplants in the USA and Europe.

The current standard of care for HCV infection uses pegylated interferon (IFN- $\alpha_{2 \mathrm{~b}}$ ) combined with ribavirin [2]. The therapy is curative in about $40 \%$ of patients [3]. According to the World Health Organization, only 30 $50 \%$ of infected patients respond to pegylated IFN + ribavirin treatment after a 48 -week course of therapy. Cure

\section{KARGER}

Fax +4161306 1234

E-Mail karger@karger.ch

www.karger.com (c) 2010 S. Karger AG, Basel

$0253-5068 / 10 / 0292-0210 \$ 26.00 / 0$

Accessible online at:

www.karger.com/bpu
Richard $\mathrm{H}$. Tullis, $\mathrm{PhD}$

Aethlon Medical Inc., 3030 Bunker Hill Street

San Diego, CA 92109 (USA)

Tel. +1 858459 7800, ext. 304, Fax +1 8582722738

E-Mail rhtullis@aethlonmedical.com 
rates are related to both viral and human genetics [4]. There are $6 \mathrm{HCV}$ genotypes and more than 50 subtypes. Genotype 1 accounts for $70-75 \%$ of all HCV infections in the USA and is associated with a $50 \%$ response rate to drug therapy. Genotypes 2 and 3 are more common in Asia and are more responsive to drug therapy [2], with genotype 2 having the best response rate at more than $80 \%$.

The principal problem with the current standard of care is that a majority of patients suffer substantial adverse effects from IFN that can limit patient compliance or cause people to avoid therapy altogether. The side effects include influenza-like symptoms, hematological abnormalities and neuropsychiatric symptoms [2]. Present research in this area is aimed at the development of new, more powerful drugs that can inhibit the action of viral proteins such as the RNA polymerase. Other potential targets include the viral envelope (entry inhibitors) and viral proteases.

We have been developing an alternative strategy using a highly selective extracorporeal filtration therapy analogous to hemodialysis $[5,6]$. This therapy combines plasmapheresis with affinity capture using lectins. Lectin affinity plasmapheresis (LAP) has been used in vitro and in clinical trials to rapidly and selectively clear viruses from blood and plasma [7].

In a recent clinical trial, hemodialysis patients infected with HCV were treated with a lectin affinity cartridge in combination with their kidney dialysis treatment [7]. Four patients received up to 3 four-hour treatments 3 times weekly. In a follow-up case study, 1 of these patients received extended treatment consisting of 12 four-hour treatment sessions on the same schedule. The LAP device caused an estimated $41 \%$ decrease in viral load in the initial studies. However, using the current data normalized to correct for variations in initial viral load gave an average $29 \%$ per treatment viral load reduction in $5 \mathrm{HCV}$-positive dialysis patients (table 1). As shown here, the predictions based on this result indicate that LAP in combination with drug therapy could reduce HCV viral load to undetectable levels in approximately 4 days, providing a substantial increase in cure rates relative to drugs alone.

\section{Methods of Analysis}

In vitro experiments have demonstrated that viral clearance using LAP is a first-order linear process in tissue culture media, plasma and human blood for a large number of different viral species [8]. Typical clearance half-times for most of these viruses range from 1 to $2 \mathrm{~h}$ in the absence of viral replication $[6,8]$. Assuming a constant flow rate and total volume, virus clearance fol-
Table 1. HCV clearance values in patients

\begin{tabular}{|c|c|c|c|}
\hline & \multicolumn{2}{|c|}{ Average $\mathrm{HCV}, \mathrm{IU} / \mathrm{ml}$} & \multirow{2}{*}{$\begin{array}{l}\text { Change } \\
\%\end{array}$} \\
\hline & before & after & \\
\hline \multicolumn{4}{|c|}{ Fortis study 1 dialysis controls } \\
\hline $\mathrm{C} 1$ & $7.90 \times 10^{7}$ & $1.49 \times 10^{7}$ & -81 \\
\hline $\mathrm{C} 2$ & $8.96 \times 10^{7}$ & $4.60 \times 10^{7}$ & -49 \\
\hline $\mathrm{C} 3$ & $4.00 \times 10^{7}$ & $3.70 \times 10^{7}$ & -91 \\
\hline \multicolumn{4}{|c|}{ Fortis study 2 dialysis controls } \\
\hline $\mathrm{C} 1$ & $1.64 \times 10^{6}$ & $5.82 \times 10^{6}$ & 256 \\
\hline $\mathrm{C} 3$ & $2.30 \times 10^{6}$ & $4.23 \times 10^{6}$ & 84 \\
\hline Mean & & & 24 \\
\hline \multicolumn{4}{|c|}{ Fortis study 1 LAP treatment + dialysis } \\
\hline $\mathrm{T} 1$ & $2.62 \times 10^{7}$ & $3.03 \times 10^{7}$ & 16 \\
\hline $\mathrm{T} 2$ & $3.72 \times 10^{7}$ & $1.86 \times 10^{7}$ & -50 \\
\hline $\mathrm{T} 3$ & $4.41 \times 10^{7}$ & $1.43 \times 10^{7}$ & -68 \\
\hline \multicolumn{4}{|c|}{ Fortis study 2 LAP treatment + dialysis } \\
\hline $\mathrm{T} 1$ & $2.64 \times 10^{6}$ & $7.30 \times 10^{5}$ & -72 \\
\hline $\mathrm{T} 3$ & $2.45 \times 10^{6}$ & $4.50 \times 10^{5}$ & -61 \\
\hline $\mathrm{T} 4$ & $2.30 \times 10^{6}$ & $4.23 \times 10^{6}$ & 48 \\
\hline T6 & $2.03 \times 10^{6}$ & $1.10 \times 10^{6}$ & -46 \\
\hline $\mathrm{T} 7$ & $2.48 \times 10^{6}$ & $3.64 \times 10^{6}$ & 46 \\
\hline T9 & $7.79 \times 10^{6}$ & $4.21 \times 10^{6}$ & -46 \\
\hline $\mathrm{T} 10$ & $5.87 \times 10^{6}$ & $4.48 \times 10^{6}$ & -24 \\
\hline $\mathrm{T} 12$ & $2.91 \times 10^{6}$ & $1.02 \times 10^{6}$ & -65 \\
\hline Mean & & & -29 \\
\hline
\end{tabular}

Fortis study 1, 2 = Study 1, entitled 'Controlled, Sequential, Phase I Safety Study to Evaluate the Use of the GNA Hemopurifier ${ }^{\circledR}$ during the Intermittent Dialysis of Subjects with End Stage Renal Disease', was a 3-treatment study involving 6 patients; study 2, entitled 'Single-Case Studies to Evaluate the Preliminary Effiacy of Prolonged Treatment of HCV with the Hemopurifier ${ }^{\mathrm{TM}}$ during Intermittent Dialysis', was a 12-treatment case study on 1 patient; both were ERB-approved studies conducted under the supervision of Dr. Vijay Kher at the Fortis Hospital in New Delhi; $\mathrm{C}=$ control; $\mathrm{T}=$ treatment.

lows an exponential decay $\mathrm{C}=\mathrm{C}_{\mathrm{o}} \cdot \mathrm{e}^{-\mathrm{ct}}$. For an apparent first-order process, the reaction half-time is related to the clearance rate by $\mathrm{t}_{1 / 2}=\ln 2 / \mathrm{c}$.

Using this formulation, we can calculate a clearance rate constant (c) from the in vivo HCV clearance rate observed for HCV in our clinical trials (table 1).

In these two studies, we observed an average HCV viral load reduction of $29 \%$ per 4 -hour treatment at a blood flow rate of 250 $\mathrm{ml} / \mathrm{min}$. This is equivalent to an 8.1-hour clearance half-time in the presence of in vivo viral replication. In contrast, there was a $24 \%$ increase in the average control viral loads over both studies. As is clear in the results presented, there was a large variation from sample to sample. Previous studies have shown that hemodialysis treatment can have some positive effect on HCV viral load which is quite variable from study to study $[9,10]$. However, such changes tend to be transient. In one study, no significant reductions in viral load were observed when followed over the course of 13 months [11]. 


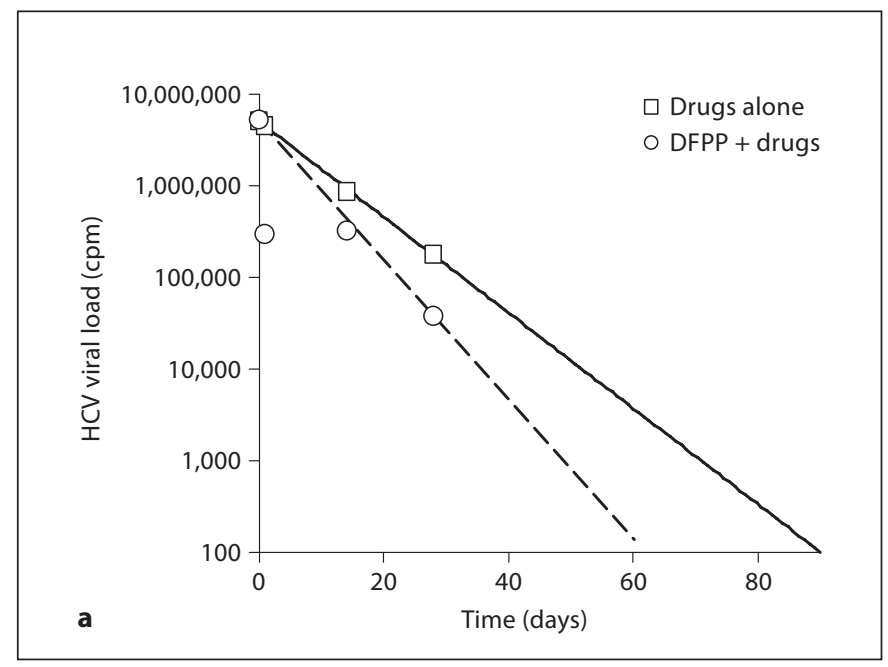

Fig. 1. a Effect of DFPP pretreatment on the response of HCV type 1 to standard-of-care drug therapy. Taken from the data of a clinical study by Fujiwara et al. [13]. The data were originally taken for 30 days and are extrapolated here for comparison with other calculations. The lines are a theoretical exponential decay. b Mod-

Inspection of the clearance equation makes clear that the most effective treatment regime would be one of continuous treatment (hemopurification) for as long a period of time as is safe. In continuous renal replacement therapy, commonly used to treat acute kidney failure, hemodialysis therapy is typically maintained for up to $24 \mathrm{~h}$ and has been used for up to 40 days on a single patient. By analogy, for continuous affinity plasmapheresis treatment, it is reasonable to suppose that a similar time frame for treatment would be safe.

In order to model the combination of the techniques, we needed an expression that combines exponential decay functions, one clearance rate for the drug treatment $(\mathrm{k})$ and one for the device treatment (c). The combined expression is given by $\mathrm{C}=\mathrm{C}_{\mathrm{o}} \mathrm{e}^{-(\mathrm{k}+\mathrm{c}) \mathrm{t}}$, where $\mathrm{k}=\mathrm{HCV}$ virus daily clearance rate during treatment with pegylated IFN + ribavirin and $c=\mathrm{HCV}$ daily clearance rate during continuous hemodialysis of $\mathrm{HCV}$ dialysis patients and $\mathrm{C}_{\mathrm{o}}=$ initial viral load in international units per milliliter. Using this formulation allows us to calculate the effect of combining continuous lectin affinity hemodialysis with standard-of-care HCV treatment in patients and compare it to the pattern for drug treatment alone. For the purposes of this discussion, the comparison applies primarily to a single continuous LAP treatment in combination with drug therapy where both mechanisms are operating.

\section{Results and Discussion}

The regimen we envision proposes continuous hemopurification to rapidly reduce $\mathrm{HCV}$ viral load for the first week of standard-of-care treatment with pegylated IFN and ribavirin [2].

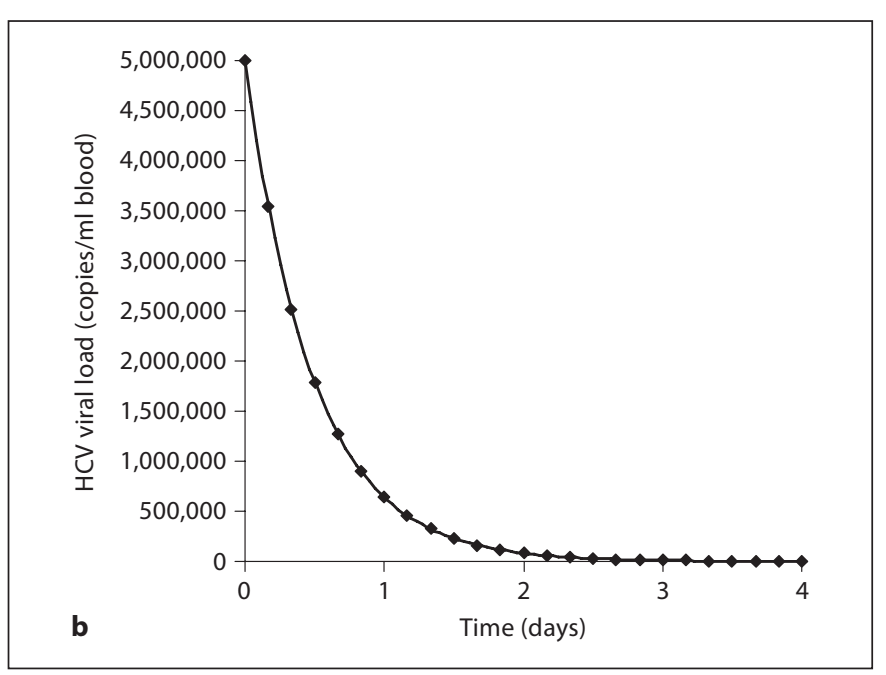

eling HCV viral load clearance during hemopurification alone from clinical studies on HCV dialysis patients: log plot exponential theory reflecting an average clearance of $29 \%$ in $4 \mathrm{~h}$ that holds true during continuous affinity hemodialysis treatment and follows the same log linear process observed in vitro.

A similar approach developed by Asahi has recently been reported to improve sustained viral response outcomes from $50 \%$ without double-filtration plasmapheresis (DFPP) to $78 \%$ in genotype $1 \mathrm{HCV}$ patients when DFPP is used in conjunction with ribavirin and pegylated IFN $[12,13]$. In DFPP, plasma from venous blood is obtained from the patient and cleared of virus particles by ultrafiltration. In this study, an average of 3 treatments were given for $3.25 \mathrm{~h}$ during the first week of drug therapy. Typical results showed an approximate 100 -fold drop in viral load in about 1 month (fig. 1a, replotted from data of Fujiwara et al. [13]). This simple 1-week pretreatment by physical virus removal increased the rate of virus clearance by the drug by approximately $33 \%$ and allowed drug therapy to be about $50 \%$ more successful in curing the infection.

These results are not without historical precedent. Table 2 shows a list of viral infections where viral load is correlated with the severity of viral disease and disease progression. For instance, it is well known that HCV is more responsive to drug therapy when the initial viral load is less than 800,000 copies $/ \mathrm{ml}$.

Thus, viral load reduction prior to or early in the treatment process should be expected to improve treatment outcomes. We have therefore looked to find more efficient methods to reduce viral load without the need for fluid replacement. 


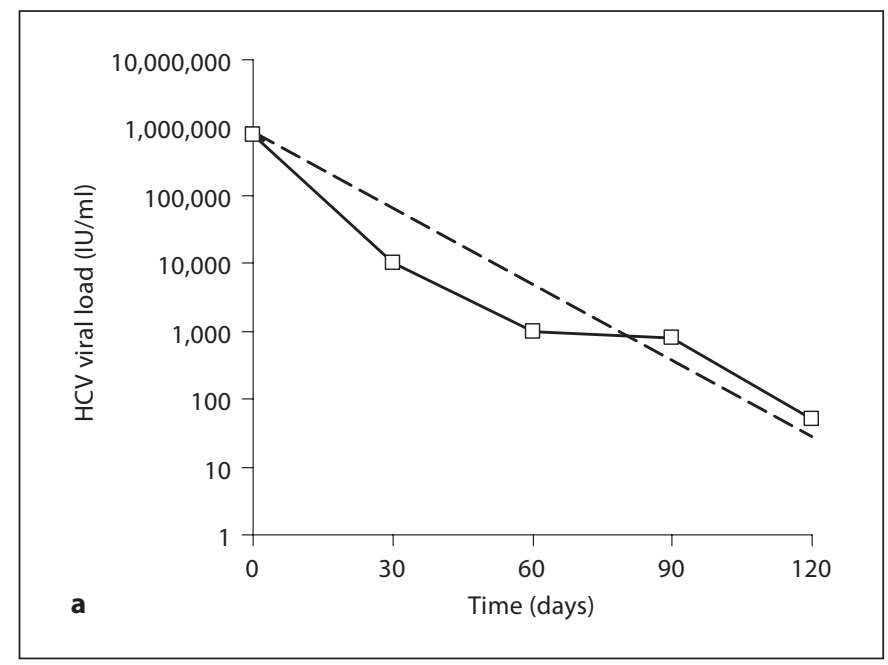

Fig. 2. a Modeling HCV viral load from patient data during IFN + ribavirin treatment $(n=34)$. The data for this figure were taken from Veillon et al. [33]. The log plot is fitted to a single exponential decay given by $\mathrm{y}=794,000^{-0.0857 t}\left(\mathrm{R}^{2}=0.873\right)$. $\mathbf{b}$ Modeling HCV viral load from patient data during IFN + ribavirin treatment in

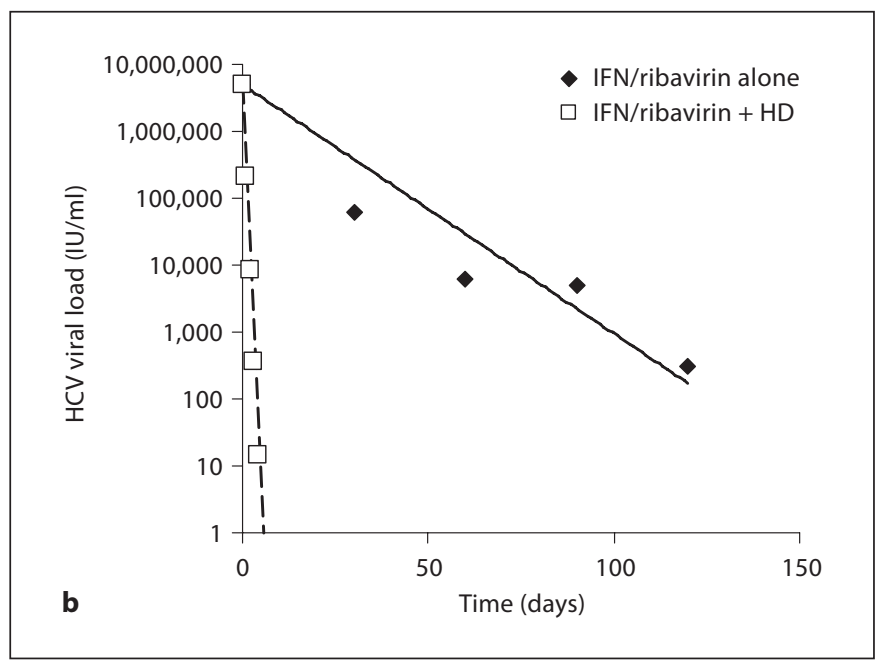

combination with affinity hemodialysis (HD). The data were recalculated and replotted against the predicted curve for the combination of continuous LAP + drug therapy. In both cases, the initial $\mathrm{HCV}$ viral load was set at $5 \times 10^{6} \mathrm{IU} / \mathrm{ml}$.

Table 2. Correlation of viral load with disease severity and outcomes

\begin{tabular}{|c|c|c|c|}
\hline Virus & Viral load correlation & $\begin{array}{l}\text { Clinical benefit/ } \\
\text { market clearance }\end{array}$ & Reference \\
\hline Dengue & lethality correlates with high viral load & yes & 14,15 \\
\hline Ebola & lethality correlates with high viral load & yes & 16,17 \\
\hline Hepatitis C & $\begin{array}{l}\text { pegylated IFN + ribavirin treatment } \\
\text { disease severity and treatment response correlates with viral load }\end{array}$ & $\begin{array}{l}\text { yes/yes } \\
\text { yes }\end{array}$ & $\begin{array}{l}18 \\
19,20\end{array}$ \\
\hline Influenza A & Tamiflu & yes/yes & 29,30 \\
\hline Marburg & plasmapheresis & yes (1 patient) & 31 \\
\hline Sin Nombre & lethality correlates with high viral load & yes & 32 \\
\hline
\end{tabular}

LAP is a good candidate for such a process. Figure $1 b$ shows the analysis of the HCV virological response predicted for continuous application of LAP in the absence of any other treatments. It shows a rapid reduction in $\mathrm{HCV}$ viral load based on a clearance rate of $29 \%$ in $4 \mathrm{~h}$ obtained in clinical studies. From this it may be calculated that starting from an initial viral load of 5 million $\mathrm{IU} / \mathrm{ml}$, continuous LAP should reduce HCV to undetectable levels in 2.28 days.

HCV Drug Therapy with Affinity

Plasmapheresis
In order to predict the full effect of performing hemopurification in conjunction with the standard of care $\mathrm{HCV}$ treatment, we analyzed the kinetics of HCV drug treatment on a typical $\mathrm{HCV}$ patient population. Veillon et al. [33] have provided such treatment data in 34 patients using a combination of pegylated IFN- $\alpha$ and ribavirin. In this study, patients infected with genotype 2 and $3 \mathrm{HCV}$ receiving weekly injections of pegylated IFN- $\alpha_{2 a}$ and daily ribavirin were studied. In these patients, a more 
than 100 -fold decrease in viral load was predictive of a sustained virus response. Among sustained responders to combination therapy, 76 out of $96(79.2 \%)$ had a viral load decrease of greater than 100 -fold after 1 month of treatment.

A plot of the data averaged for the patients who showed a sustained virological response is shown in figure $2 \mathrm{a}$. The rate of virus clearance during treatment was evaluated using a single exponential function. The clearance rate constant here was $\mathrm{k}=0.0857$ per day corresponding to an overall half-time of 8.09 days. While the data is clearly biphasic, a single exponential fit simplifies the picture and gives a reasonable correlation coefficient of $87 \%$.

Figure $2 \mathrm{~b}$ shows the results of combining drug treatment with 1 session of continuous LAP versus drug treatment alone. The striking feature of this comparison is that the combination treatment of continuous LAP with standard-of-care pegylated INF- $\alpha+$ ribavirin is predicted to proceed significantly faster than drug treatment alone. In this regard it is similar to DFPP, with the primary difference that continuous LAP-mediated virus clearance is at least 10 times faster and will also clear immunosuppressive free viral proteins and viral fragments which would be missed by DFPP.

\section{Conclusions}

Physical reduction of viral load has been demonstrated to substantially improve HCV cure rates. Based on the observed rates of virus clearance in clinical studies, we calculate that LAP applied continuously for 4.1 days would reduce $\mathrm{HCV}$ viral load to undetectable levels versus more than 30 days measured for DFPP in combination with drugs. This calculation suggests that 1 week of pretreatment with LAP used in combination with standard HCV drug therapy would probably lead to cure rates of more than $80 \%$.

\section{References}

1 Kim WR: The burden of hepatitis $\mathrm{C}$ in the United States. Hepatology 2002;36(suppl 1): S30-S34.

-2 National Institutes of Health Consensus Development Conference Statement: Management of hepatitis C 2002 (June 10-12, 2002). Gastroenterology 2002;123:2082-2099.

- 3 Rosen HR, Ribeiro RR, Weinberger L, Wolf S, Chung M, Gretch DR, Perelson AS: Early hepatitis $C$ viral kinetics correlate with longterm outcome in patients receiving high dose induction followed by combination interferon and ribavirin therapy. J Hepatol 2002;37: 124-130.

4 Ge D, Fellay J, Thompson AJ, Simon JS, Shianna KV, Urban TJ, Heinzen EL, Qiu P, Bertelsen AH, Muir AJ, Sulkowski M, McHutchison JG, Goldstein DB: Genetic variation in IL28B predicts hepatitis C treatment-induced viral clearance. Nature 2009.

5 Tullis R, Scammura D, Ambrus J: Affinity hemodialysis for antiviral therapy with specific application to HIV. J Theor Med 2002; 3:157-166.

6 Tullis RH: Method for removal of viruses from blood using lectin affinity hemodialysis. San Diego, Aethlon Medical Inc, 2007.

7 Tullis RH, Duffin RP, Handley HH, Sodhi P, Menon J, Joyce JA, Kher V: Reduction of hepatitis $\mathrm{C}$ virus using lectin affinity plasmapheresis in dialysis patients. Blood Purif 2009;27:64-69.
8 Tullis RH, Duffin RP, Zech M, Ambrus JL Jr: Affinity hemodialysis for antiviral therapy. I. Removal of HIV-1 from cell culture supernatants, plasma, and blood. Ther Apher 2002;6:213-220.

-9 Badalamenti S, Catania A, Lunghi G, Covini G, Bredi E, Brancaccio D, Salvadori M, Como G, Ponticelli C, Graziani G: Changes in viremia and circulating interferon-alpha during hemodialysis in hepatitis $\mathrm{C}$ virus-positive patients: only coincidental phenomena? Am J Kidney Dis 2003;42:143-150.

-10 Mizuno M, Higuchi T, Yanai M, Kanmatsuse K, Esumi M: Dialysis-membrane-dependent reduction and adsorption of circulating hepatitis $\mathrm{C}$ virus during hemodialysis. Nephron 2002;91:235-242.

11 Fabrizi F, Bunnapradist S, Lunghi G, Martin $P$ : Kinetics of hepatitis $C$ virus load during hemodialysis: novel perspectives. J Nephrol 2003;16:467-475.

12 Takada Y, Ito T, Ueda Y, Haga H, Egawa H, Tanaka K, Uemoto S: Effects of double-filtration plasmapheresis combined with interferon plus ribavirin for recurrent hepatitis $\mathrm{C}$ after living donor liver transplantation. Liver Transpl 2008;14:1044-1047.

13 Fujiwara K, Kaneko S, Kakumu S, Sata M, Hige S, Tomita E, Mochida S: Double filtration plasmapheresis and interferon combination therapy for chronic hepatitis $\mathrm{C}$ patients with genotype 1 and high viral load. Hepatol Res 2007;37:701-710.
14 Wang WK, Chao DY, Kao CL, Wu HC, Liu YC, Li CM, Lin SC, Ho ST, Huang JH, King CC: High levels of plasma dengue viral load during defervescence in patients with dengue hemorrhagic fever: implications for pathogenesis. Virology 2003;305:330-338.

15 Vaughn DW, Green S, Kalayanarooj S, Innis BL, Nimmannitya S, Suntayakorn S, Endy TP, Raengsakulrach B, Rothman AL, Ennis FA, Nisalak A: Dengue viremia titer, antibody response pattern, and virus serotype correlate with disease severity. J Infect Dis 2000;181:2-9.

16 Drosten C, Gottig S, Schilling S, Asper M, Panning M, Schmitz H, Gunther S: Rapid detection and quantification of RNA of Ebola and Marburg viruses, Lassa virus, CrimeanCongo hemorrhagic fever virus, Rift Valley fever virus, dengue virus, and yellow fever virus by real-time reverse transcriptionPCR. J Clin Microbiol 2002;40:2323-2330.

17 Towner JS, Rollin PE, Bausch DG, Sanchez A, Crary SM, Vincent M, Lee WF, Spiropoulou CF, Ksiazek TG, Lukwiya M, Kaducu F, Downing R, Nichol ST: Rapid diagnosis of Ebola hemorrhagic fever by reverse transcription-PCR in an outbreak setting and assessment of patient viral load as a predictor of outcome. J Virol 2004;78:4330-4341. 
18 Rivera M, Gentil MA, Sayago M, Gonzalez Roncero F, Trigo C, Algarra G, Pereira P, Valdivia MA, Aguilar J: Treatment of hepatitis $C$ virus with interferon in hemodialysis patients awaiting kidney transplant. Transplant Proc 2005;37:1424-1425.

19 Kao JH, Lai MY, Chen PJ, Hwang LH, Chen DS: Serum hepatitis $C$ virus titers in the progression of type $\mathrm{C}$ chronic liver disease. With special emphasis on patients with type $1 \mathrm{~b}$ infection. J Clin Gastroenterol 1996;23:280 283.

20 Shiffman ML, Hofmann CM, Thompson EB, Ferreira-Gonzalez A, Contos MJ, Koshy A, Luketic VA, Sanyal AJ, Mills AS, Garrett CT: Relationship between biochemical, virological, and histological response during interferon treatment of chronic hepatitis $C$. Hepatology 1997;26:780-785.

-21 Bossi P: Genital herpes: epidemiology, transmission, clinic, asymptomatic viral excretion, impact on other sexually transmitted diseases, prevention, and treatment. Ann Dermatol Venereol 2002;129:477-493.
22 Haas J, Meyding-Lamade U, Fath A, Stingele K, Storch-Hagenlocher B, Wildemann B: Acyclovir treatment of experimentally induced herpes simplex virus encephalitis: monitoring the changes in immunologic $\mathrm{NO}$ synthase expression and viral load within brain tissue of SJL mice. Neurosci Lett 1999; 264:129-132.

23 Clerici M: Immunomodulants for the treatment of HIV infection: the search goes on. Expert Opin Investig Drugs 2006;15:197200.

24 Rathbun RC, Lockhart SM, Stephens JR: Current HIV treatment guidelines - an overview. Curr Pharm Des 2006;12:1045-1063.

25 Levy JA: HIV pathogenesis and long-term survival. Aids 1993;7:1401-1410.

- 26 Buchbinder SP, Katz MH, Hessol NA, O'Malley PM, Holmberg SD: Long-term HIV-1 infection without immunologic progression. Aids 1994;8:1123-1128.

27 Deacon NJ, Tsykin A, Solomon A, Smith K, Ludford-Menting M, Hooker DJ, McPhee DA, Greenway AL, Ellett A, Chatfield C, Lawson VA, Crowe S, Maerz A, Sonza S, Learmont J, Sullivan JS, Cunningham A, Dwyer D, Dowton D, Mills J: Genomic structure of an attenuated quasi species of HIV-1 from a blood transfusion donor and recipients. Science 1995;270:988-991.
28 Cohen J: Controls sought. Science 2006;313: 1029.

29 Oxford JS, Mann A, Lambkin R: A designer drug against influenza: the NA inhibitor oseltamivir (Tamiflu). Expert Rev Anti Infect Ther 2003;1:337-342.

30 McClellan K, Perry CM: Oseltamivir: a review of its use in influenza. Drugs 2001;61: 263-283.

31 Nikiforov V, Turovskii I, Kalinin P, Akinfeeva L, Katkova L, Barmin V, Riabchikova E, Popkova N, Shestopalov A, Nazarov V, et al: A case of a laboratory infection with Marburg fever. Zh Mikrobiol Epidemiol Immunobiol 1994;3:104-106.

32 Terajima M, Hendershot JD 3rd, Kariwa H, Koster FT, Hjelle B, Goade D, DeFronzo MC, Ennis FA: High levels of viremia in patients with the Hantavirus pulmonary syndrome. J Infect Dis 1999;180:2030-2034.

33 Veillon P, Payan C, Picchio G, ManiezMontreuil M, Guntz P, Lunel F: Comparative evaluation of the total hepatitis $\mathrm{C}$ virus core antigen, branched-DNA, and Amplicor monitor assays in determining viremia for patients with chronic hepatitis $\mathrm{C}$ during interferon plus ribavirin combination therapy. J Clin Microbiol 2003;41:3212-3220. 